\title{
UPAYA MENINGKATKAN KEPUASAN WISATAWAN MELALUI THE ATTRACTION OF TOUR DI TJP SERATOUR
}

\author{
Oce Ridwanudin \\ Nugraha Adi Saputra
}

Manajemen Pemasaran Pariwisata, FPIPS UPI

\begin{abstract}
The attraction of tourists to use the tour affecting travel services until they feel the satisfaction or dissatisfaction as a result of the products and services provided to tourists by a company providing travel services. This research was conducted with the aim to describe the attraction of the tour at the TJP Seratour, tourist satisfaction and the influence of the attraction of the tour to tourist satisfaction. The population in this study is the tourists who use the services of a travel in Seratour TJP 100 respondents. The method used is descriptive and verification with research time of less than one year (cross-sectional method). The sampling technique used is systematic random sampling. The data analysis technique used is the technique of multiple regression analysis. Hasi This study shows that the highest impact on the attraction of the tour is the variable sub lowest access and influence is convenience. Simultaneously te attraction of the tour to have a significant impact on tourist satisfaction, the same thing happens to the partial test, which occurred a significant influence between the attraction of the tour to tourist satisfaction.
\end{abstract}

Keywords: The attraction of the tour, tourist satisfaction, TJP Seratour

\section{PENDAHULUAN}

Industri pariwisata menjadi salah satu industri yang menjadi salah satu pengasil pendapatan daerah terbesar di beberapa negara dan beberapa kota. Indonesia adalah salah satu negara yang menjadi daerah tujuan wisata utama di dunia, kekayaan alam yang melimpah dan ragam budaya yang dimiliki Indonesia menjadi salah satu daya tarik utama di Indonesia.

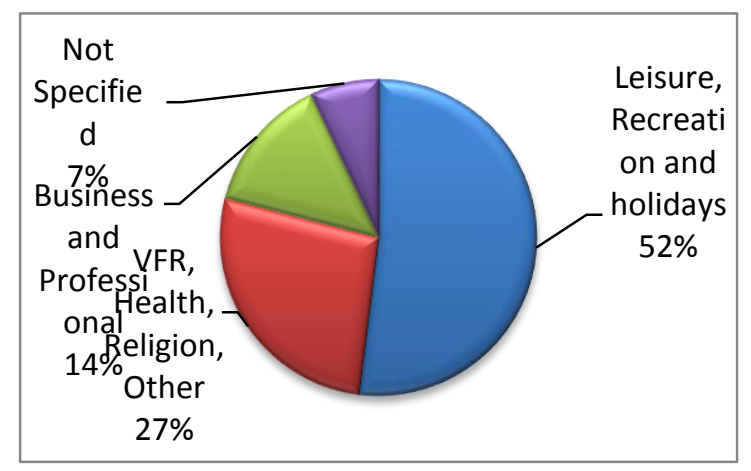

Dari Gambar 1.1 diatas dapat dilihat bahwa sebagian besar masayarakat dunia melakukan perjalanan hanya untuk berwisata, hal tersebut membuat tingkat kunjungan wisata di suatu negara dan daerah di negara tersebut terus meningkat, hal tersebut harus diimbangi dengan kesiapan daerah tujuan wisata untuk menampung dan melayani para wisatawan yang datang berkunjung ke suatu negara atau daerah tujuan wisata.

Dalam perkembangannya industri pariwisata di Indonesia juga terus berkembang, mulai dari jumlah akomodasi yang dapat menunjang kegiatan pariwisata hingga perusahaan jasa perjalanan wisata yang sering dikenal dengan sebutan travel agent. Tavel agent merupakan salah satu perusahaan yang membantu wisatawan dalam melakukan kegiatan berwisata dengan cara menjadi perantara atau oenyedia jasa akomodasi, transportasi dan lain sebagainya untuk nmemudahkan wisatawan dalam melaksanakan perjalanan wisata.

PT. TJP Seratour merupakan salah satu perusahaan di Kota Bandung yang bergerak di bidang jasa pariwisata, Seratour yang berkedudukan di Jl. Ir. H.Djuanda No.477, Bandung melayani para wisatawan dengan beberapa produk andalannya yaitu, rental bis, mobil dan motor, paket wisata, voucher hotel, jasa layanan shuttle dan lain sebagainya yang berkaitan dengan kegiatan berwisata. Seratour ternyata memiliki sedikit masalah mengenai kepuasan wisatawan, dengan beberapa strategi yang telah dilakukan oleh seratour untuk mendapatkan pelanggan dan memberikan kepuasan pada pelanggannya ternyata belum mebuat seratour berhasil dalam menciptakan kepuasan wisatawan. Berikut merupakan data kepuasan pelanggan TJP Seratour: 


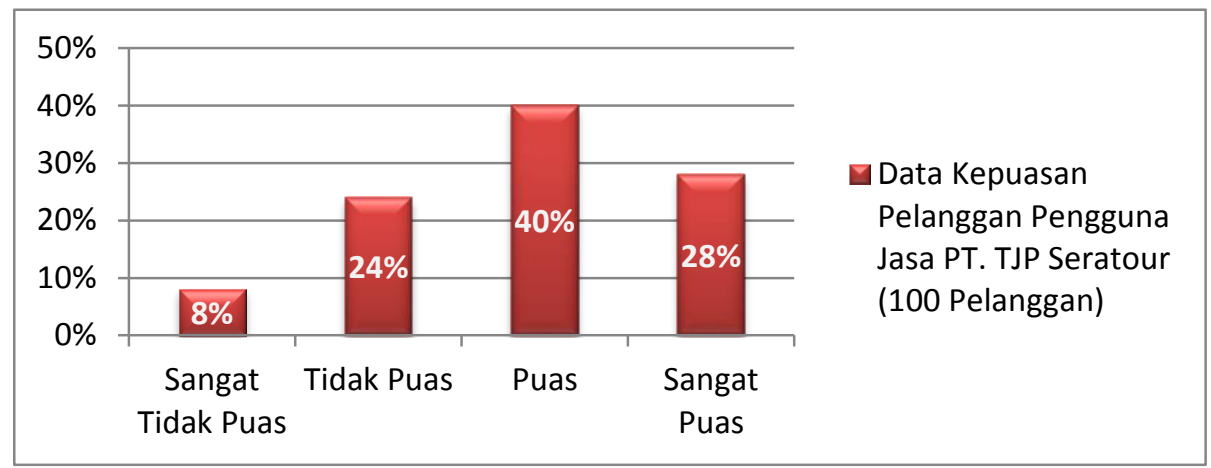

Gambar 1.2

Data Kepuasan Pengguna Jasa di PT. TJP Seratour 100 Pengguna Jasa

Sumber: Pengolahan data 2014 PT. TJP Seratour

Tabel 1.5 menunjukan tingkat kepuasan wisatawan yang menggunakan jasa seratour, meskipun dalam tabel tersebut menunjukan bahwa sebagian besar wisatawan merasa puas terhadap poduk dan pelayanan seratour, namun hal tersebut ternyata tidak mencapai target tingkat kepuasan wisatawan yang ditargetkan oleh seratour seperti yang diungkapkan langsung oleh General Manager sekaligus Owner dari PT. TJP Seratour yaitu Ibu Irma Rahmawati yang menegaskan bahwa "target kepuasan perusahaan kami untuk tahun ini harus mencapai lebih dari $80 \%$ atau minimal mencapai angka $80 \%$ wisatawan yang menggunakan jasa perusahaan kami merasa puas atas produk dan pelayanan yang perusahaan kami berikan" begitu penegasan dari Ibu Irma Rahmawati.

Kepuasan wisatawan merupakan hal yang patut menjadi prioritas bagi perusahaan yang bergerak dibidang jasa pariwisata. Puas atau tidak puasnya wisatawan dapat menimbulkan dampak positif atau negatif terhadap perusahaan, kepuasan wisatawan menimbulkan dampak positif bagi perusahaan diantaranya word of mouth yang positif dari wisatawan mengenai perusahaan, perekomendasian penggunaan jasa perusahaan yang sama, selain itu juga kepuasan wisatawan dapat menjadi salah satu alat pemasaran juga dengan menjadikan wisatawan yang merasa puas sebagai bukti bahwa perusahaan memiliki kapabilitas yang tinggi dalam bidangnya dalam bentuk testimonial. Dampak negatif yang didapatkan perusahaan yang merasa tidak puas juga menjadi dampak yang sangat merugikan bagi perusahaan, salah satunya adalah word of mouth yang negatif, tidak merekomendasikan menggunakan jasa perusahaan tersebut, hingga adanya black list dari wisatawan yang mungkin dapat dipublikasikan dalam akun social media yang dapat dilihat banyak orang yang akhirnya dapat menjadi salah satu penyebab kurangnya permintaan akan produk dari perusahaan tersebut.

Menurut data yang ada, tidak tercapainya target merusahaan mengenai kepuasan wisatawan disebabkan oleh kurang puasnya wisatawan

terhadap fasilitas yang diberikan oleh perusahaan, sehingga membuat wisatawan merasa kurang nyaman dengan perjalanan wisatanya. Tidak hanya fasilitas namun kesesuaian konten produk yang dijanjikan juga terkadang melenceng dari kesepakatan yang telah disepakati sebelumnya.

Selain itu juga ketidak puasan wisatawan di seratour dapat disebabkan oleh kapabilitas karyawan yang tidak sesuai dengan yang diharapkan oleh wisatawan, seperti kapabilitas tour leader/tour guide dalam memandu suatu perjalanan wisata. Ketidakpuasan juga dapat terjadi dikarenakan wisatawan tidak dapat memahami atau memiliki ekspektasi yang berlebih terhadap suatu produk yang ditawarkan maupun konten-konten yang ada didalamnya, terkadang konsumen juga tidak mengerti akan situasi dan kondisi yang ada pada saat produk tersebut digunakan, apabila dalam produk paket wisata dapat diambil contoh situasi dan kondisi dilapangan yang tidak memungkinkan untuk melakukan suatu aktifitas wisata dapat menimbulkan kekecewaan dan wisatawan merasa tidak puas padahal hal tersebut menyangkut keamanan, kenyamanan bahkan keselamatan wisatawan itu sendiri.

Untuk mendapatkan pelanggan dan menciptakan kepuasan pelanggan seratour telah melakukan strategi - strategi terbaiknya, seratour menggunakan strategi e-marketing untuk mempermudah para wisatawan dari luar kota untuk mendapatkan informasi mengenai produk - produk yang disediakan oleh seratour, seratour juga mempermudah proses transaksi dengan memberikan penawaran melalui email, pembayaran juga dapat dilakukan melalui transfer antar bank. Selain itu, seratour juga mulai melakukan strategi direct marketing untuk dapat tetap eksis di dalam Kota Bandung.

Menciptakan kepuasan pelanggan bukanlah sesuatu yang mudah dilakukan oleh perusahaan, banyak hal yang harus diperhatikan dalam proses pencapaian kepuasan pelanggan. Dalam menciptakan kepuasan pelanggan tidak hanya mengenai produk yang berkulitas saja, akan tetapi 
pelayanan yang diberikan juga harus baik agar dapat memberikan nilai tambah bagi perusahaan penyedia jasa pariwisat. Banyak strategi perusahaan yang dapat digunakan untuk menciptakan suatu kepuasan pelanggan salah satunya adalah service quality dan The Attraction Of Tour.

The attraction of tour (Frost, 2004) merupakan salah satu strategi untuk menarik wisatawan untuk menggunakan jasa perjalanan wisata daripada berwisata secara individu, yang didalamnya terdapat sub variabel price, expertise, convenience dan access. Hal tersebut diterapkan oleh TJP Seratour dalam memasarkan produk paket perjalanan wisatanya yang didalamnya terdapat aspek - aspek tersebut, selain dapat menarik wisatawan untuk menggunakan jasa perjalanan wisata dari TJP Seratour namun juga mampu memberikan kepuasan tersendiri kepada wisatawan yang menggunakan jasa perjalanan wisata tersebut. Maka dari itu dalam penelitian ini akan meneliti mengenai pengaruh dari the attraction of tour terhadap kepuasan wisatawan di TJP Seratour dengan judul "Upaya Meningkatkan Kepuasan Wisatawan Melalui The Attraction of Tour" dengan objek penelitian yaitu PT. TJP Seratour Bandung, dan akan dilakkan survei terhadap wisatawan yang telah menggunakan jasa perjalanan wisata.

\subsection{Rumusan Masalah}

Dari latar belakang diatas, maka dapat dirumuskan masalah sebagai berikut.

1. Bagaimana The Attraction of Tours di PT. TJP Seratour?

2. Bagaimana kepuasan pelanggan di PT. TJP Seratour?

3. Bagaimana pengaruh The Attraction of Tours terhadap kepuasan pelanggan?

\subsection{Tujuan Penelitian}

Adapun tujuan dari penelitian ini adalah untuk mempelajari, mendeskripsikan, menganalisis dan menjelaskan hasil temuan tentang:

1. Untuk memperoleh temuan mengenai The Attraction of Tours di PT. TJP Seratour

2. Untuk memperoleh temuan mengenai kepuasan pelanggan di PT. TJP Seratour

3. Untuk memperoleh temuan bagaimana pengaruh The Attraction of Tours terhadap kepuasan wisatawan di TJP Seratour

\subsection{Kegunaan Penelitian}

Hasil yang diperoleh dari penelitian ini diharapkan dapat memberikan kegunaan:

\section{Kegunaan Teoritis}

Secara teoritis, hasil penelitian ini dapat digunakan untuk melakukan pengembangan ilmu manajemen pemasaran pariwisata pada destinasi, khususnya untuk perusahaan tours \& travel dengan mengkaji hal The Attraction of Tours serta kepuasan pelanggan pada perusahaan tours \& travel.

\section{Kegunaan Praktis}

Secara empirik, hasil penelitian ini dapat mendorong para pengusaha jasa tours \& travel khususnya untuk PT. TJP Seratour untuk lebih memperhatikan kepuasan pelanggan dengan cara memberikan pelayanan dan produk trbaik kepada para konsumen dan menjadi saah satu referensi evaluasi bagi perusahaan jasa tours \& travel agar dapat terus memberikan pelayanan yang baik.

\section{KAJIAN PUSTAKA \\ 2.1 The Attraction Of Tour Sebagai Salah \\ Satu Konsep Tourism and Hospitality \\ Marketing}

Marketing menjadi hal yang diperlukan untuk memperkenalkan dan memasarkan barang atau jasa yang dimiliki oleh setiap perusahaan, marketing adalah salah satu cara untuk menarik konsumen agar mau menggunakan barang atau jasa yang dipasarkan, pemasar juga harus mampu memahami dan memenuhi keinginan konsumen bukan hanya memperkenalkan dan menjual produk begitu saja tanpa memperhatikan kebutuhan dan keinginan pelanggan. Seperti yang diungkapkan oleh Kotler \& Amstrong (2012, hal:5)

Marketing must be understood not in the old sense of making a sale - "telling and selling"but in the new sense of satisfying customer needs. If the marketer understands consumer needs; develops products that provide superior customer value; and prices, distributes, and promotes them effectively, these products will sell easily.

Menurut Kotler dan Keller (2012, hlm. 5) "Marketing management as the art and science of choosing target markets and getting, keeping, and growing customers through creating, delivering, and communicating superior customer value". Dapat diartikan bahwa manajemen pemasaran sebagai seni dan ilmu memilih pasar sasaran dan meraih, mempertahankan, serta menumbuhkan pelanggan dengan menciptakan, menghantarkan, dan mengkomunikasikan nilai pelanggan yang unggul.

Tourism and Hospitality Marketing merupakan suatu konsep untuk memasarkan produk - produk pariwisata yang berupa jasa pariwisata. Travel agent memiliki kontribusi yang sangat besar terhadap proses pemasaran pariwisata di Indonesia maupun di dunia, hal tersebut juga diungkapkan oleh Simon Hudson pada bukunya yang berjudul Tourism and Hospitality Marketing yang menyatakan bahwa travel agent masuk kedalam salah satu alat pendistribusian produk pariwisata seperti yang dijelaskan dalam kutipan berikut ini "Travel agent is marketing intermediaries that offer the tourism customer a variety of services, including everything from transportation plans and tour packages to insurance services and accommodation" 
(2008:223). Dalam kutipan tersebut dijelaskan bahwa travel agent merupakan intermediaris yaitu penghubung antara wisatawan dengan penyedia jasa pariwisata seperti penyedia jasa transportasi dan akomodasi lainnya yang dibutuhkan wisatawan dalam menjalankan kegiatan berwisatanya. Kutipn tersebut juga menjelaskan bahwa salah satu yang produk yang dimiliki oleh travel agent adalah tour package.

Tour Package juga memiliki kesamaan dengan package holiday, menurut Jelizaveta Kozlova (2014 : 12) mengemukakan definisi dari package holidays sebagai berikut:

"Package holidays are those which include transport, accommodation, ground arrangements and the services of a tour operator's representative for an all-in-price. Package holidays may be sold by the tour operator directly to the public or more often they sell through a travel agent who is paid commission for the sale"

Artinya package holidays merupakan produk yang didalamnya terdapat fasilitas seperti transportasi, akomodasi, ground arrangements dan servis dalam sebuah tour dengan harga all-in-price.

Begitu banyak jenis strategi pemasaran yang ada membuat konsep - konsep pemasaran yang baru, baik itu seluruhnya konsep yang baru, diadaptasi dari konsep berikutnya bahkan mungkin terdapat persamaan yang sangat kuat diantara konsep satu dengan konsep lainnya. Salah satunya adalah persamaan dari konsep tour package dan the attraction of tour, seperti yang telah dipaparkan diatas tour package ternyata memiliki kemiripan dengan konsep the attraction of tour dimulai dari kesamaan tujuan konsep tersebut dibuat, salah satunya adalah untuk menarik minat wisatawan untuk menggunakan jasa perjalanan wisata dengan beberapa kelebihan dan kemudahan yang ditawarkan.

The attraction of tour merupakan suatu konsep yang tujuannya adalah untuk menarik minat wisatawan untuk menggunakan jasa perjalanan wisata seperti yang dikemukakan oleh Warwick Frost (2004:76-77) "the attraction of tour is why do tourists choose to participate in tours, as opposed to travelling independently?". Yang didalamnya memiliki beberapa dimensi yang secara tidak langsung berkaitan ataupun sama dengan konsep tour package/package tour yaitu price, expertise, convenience dan access.

\subsection{Kepuasan Wisatawan}

Kotler dalam Khazaei, Manjiri, Samiey, Najafi (2014, hal:17) Customer satisfaction as a customer's feelings of pleasure or disappointment resulting from comparing the product's perceived performance in relation to customers' expectations.

\subsection{Paradigma Penelitian}

Paradigma penelitian yang merupakan cara pandang peneliti dalam melihat pengaruh the attraction of tour terhadap keputusan pembelian tiket maskapai penerbangan domestik pada gambar 2.1 dibawah ini.

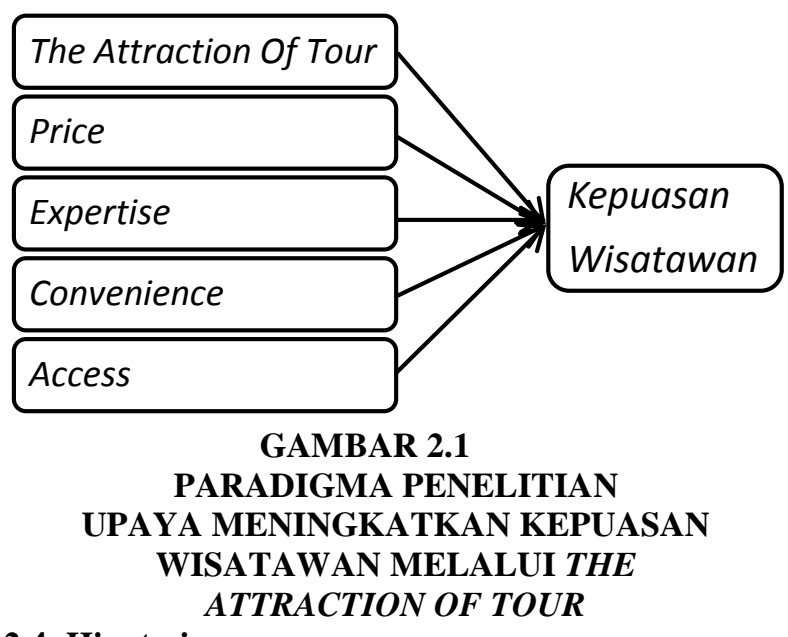

\subsection{Hipotesis}

Berdasarkan pemaparan ini, maka peneliti mengemukakan hipotesis sebagai berikut:

"Terdapat pengaruh antara The Attraction of Tour Terhadap Kepuasan Wisatawan"

\section{METODE PENELITIAN}

\subsection{Objek Penelitian}

Penelitian ini menganalisis tentang pengaruh the attraction of tour terhadap kepuasan wisatawan. Objek penelitian ini adalah salah satu perusahaan yang bergerak di bidang jasa perjalanan wisata yaitu PT. TJP Seratour, yang menjadi variabel bebas (independent variable) adalah the attraction of tour $(\mathrm{X})$ yang terdiri dari empat dimensi yaitu price $\left(\mathrm{X}_{1}\right)$, expertise $\left(\mathrm{X}_{2}\right)$ convenience $\left(\mathrm{X}_{3}\right)$. Sedangkan yang menjadi variabel terikat (dependent variable) adalah kepuasan wisatawan (Y) memiliki indikator yaitu kepuasan terhadap price, expertise, convenience dan access.

Unit analisis dalam penelitian ini adalah wisatawan yang menggunakan jasa perjalanan wisata di TJP Seratour.

\subsection{Metode Penelitian}

Berdasarkan variabel-variabel yang diteliti maka metode penelitian yang dipergunakan adalah metode penelitian deskriptif dan verifikatif.

\subsection{Metode Penarikan Sampel}

Ukuran sampel dihitung dengan menggunaan rumus Slovin (Husein Umar, 2010:131). Berdasarkan rumus tersebut, dengan derajat kesalahan sebesar $10 \%$, maka jumlah responden yang dijadikan ukuran sampel dalam penelitian ini ialah sebanyak 100 responden.

\subsection{Teknik Pengumpulan Data}

Teknik pengumpulan data yang digunakan oleh penulis adalah sebagai berikut:

1. Angket (Kuesioner)

2. Wawancara

3. Observasi 
4. Studi Literatur

3.5 Pengujian Validitas dan Reliabilitas

Selanjutnya, sebelum didistribusikan kepada responden, instrumen penelitian yang berupa kuesioner diuji terlebih dahulu. Uji yang dilakukan meliputi uji validitas dan reliabilitas. Hasil menunjukan bahwa instrumen penelitian valid dan reliabel.

\subsection{Pengujian Hipotesis}

Proses untuk menguji hipotesis dimana metode analisis yang dilakukan dalam penelitian ini adalah metode analisis verifikatif, maka dilakukan teknik analis regresi berganda (multiple regression).

Analisis regresi berganda adalah hubungan secara linear antara dua atau lebih variabel independent $\left(\mathrm{X}_{1}, \mathrm{X}_{2}, \mathrm{X}_{3}, \mathrm{X}_{4}\right)$ dengan variabel dependent (Y). Analisis ini untuk mengetahui arah hubungan antara variabel independent dengan variabel dependent apakah masing-masing variabel independent berhubungan positif atau negatif dan untuk memprediksi nilai dari variabel dependent apabila nilai variabel independent mengalami kenaikan atau penurunan. Data yang digunakan biasanya berskala interval atau rasio. Lebih jelasnya dapat dilihat pada gambar 3.1 berikut:

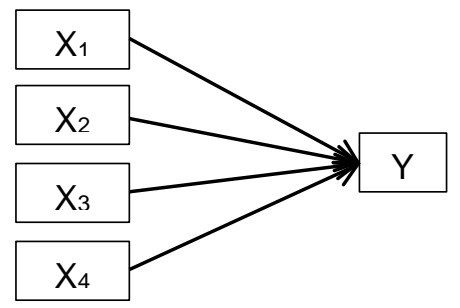

Keterangan :

$\begin{array}{ll}\mathrm{X}_{1} & : \text { Price } \\ \mathrm{X}_{2} & : \text { Expertise } \\ \mathrm{X}_{3} & : \text { Convenience } \\ \mathrm{X}_{4} & : \text { Access } \\ \mathrm{Y} & : \text { Kepuasan Wisatawan }\end{array}$

Gambar 3.1

Regresi BergandaKriteria pengambilan keputusan hipotesis secara statistik dalam rangka pengambilan keputusan penerimaan atau penolakan hipotesis dapat ditulis sebagai berikut:

\section{Secara Simultan}

A. $\mathrm{H}_{0}=0$, tidak terdapat pengaruh yang signifikan dari the attraction of tour teradap kepuasan wisatawan yang menggunakan paket wisata.

B. Ha $\neq 0$, terdapat pengaruh dari the attraction of tour teradap kepuasan wisatawan yang menggunakan paket wisata.

\section{Secara Parsial}

A. Ho $=0$, artinya tidak terdapat pengaruh yang signifikan antara price pada kepuasan wisatawan yang menggunakan paket wisata.

B. $\mathrm{Ha} \neq 0$, terdapat pengaruh yang signifikan antara price pada kepuasan wisatawan yang menggunakan paket wisata.

C. Ho $=0$, artinya tidak terdapat pengaruh yang signifikan antara expertise pada kepuasan wisatawan yang menggunakan paket wisata.

D. Ha $\neq 0$, terdapat pengaruh yang signifikan antara expertise pada kepuasan wisatawan yang menggunakan paket wisata.

E. Ho $=0$, artinya tidak terdapat pengaruh yang signifikan antara convenience pada kepuasan wisatawan yang menggunakan paket wisata.

F. Ha $\neq 0$, terdapat pengaruh yang signifikan antara convenience pada kepuasan wisatawan yang menggunakan paket wisata.

G. Ho $=0$, artinya tidak terdapat pengaruh yang signifikan antara acces pada kepuasan wisatawan yang menggunakan paket wisata.

H. $\mathrm{Ha} \neq 0$, terdapat pengaruh yang signifikan antara acces pada kepuasan wisatawan yang menggunakan paket wisata.

IV. HASIL PENELITIAN DAN PEMBAHASAN

4.1 Hasil Tanggapan Responden Terhadap The Attraction of Tour Di PT. TJP Seratour

TABEL 4.1

REKAPITULASI TANGGAPAN RESPONDEN TERHADAP THE ATTRACTION OF TOUR PT. TJP SERATOUR

\begin{tabular}{|c|c|c|c|c|}
\hline No & Sub Variabel & $\begin{array}{l}\text { Total } \\
\text { Skor }\end{array}$ & $\begin{array}{c}\text { Skor } \\
\text { Rata- } \\
\text { rata }\end{array}$ & $\%$ \\
\hline 1 & Price & 1197 & 239.4 & 24.88 \\
\hline 2 & Expertise & 1219 & 243.8 & 25.34 \\
\hline 3 & Convenience & 1219 & 243.8 & 25.34 \\
\hline 4 & Access & 1176 & 235.2 & 24.44 \\
\hline \multicolumn{2}{|r|}{ Total } & 4811 & 962.2 & 100 \\
\hline
\end{tabular}

Sumber: Hasil Pengolahan Data, 2015

Tabel 4.1 menjelaskan bahwa dimensi yang mendapatkan penilaian paling tinggi adalah expertise dan convenience, dan nilai terendah dalam penelitian ini adalah access.

Hal tersebut mungkin disebabkan oleh wisatawan menilai bahwa keadaan pada saat melakukan perjalanan wisata merasa bahwa wisatawan mendapatkan kenyamanan baik dalam perjalanan, di daerah tujuan wisata, ataupun secara keseluruhan dari kegiatan berwisata dan juga merasakan bahwa kemampuan dan keahlian karyawan baik dari pemandu wisata ataupun staf yang bertugas di sebagai pemasar. 
Tanggapan responden mengenai the attraction of tour mendapatkan total skor senilai 4.811yang menunjukan bahwa the attraction of tour memiliki posisi yang baik dibenak wisatawan yang menggunakan jasa perjalanan wisata di TJP Seratour seperti yang ditunjukan dalam garis kontinum dibawah ini.

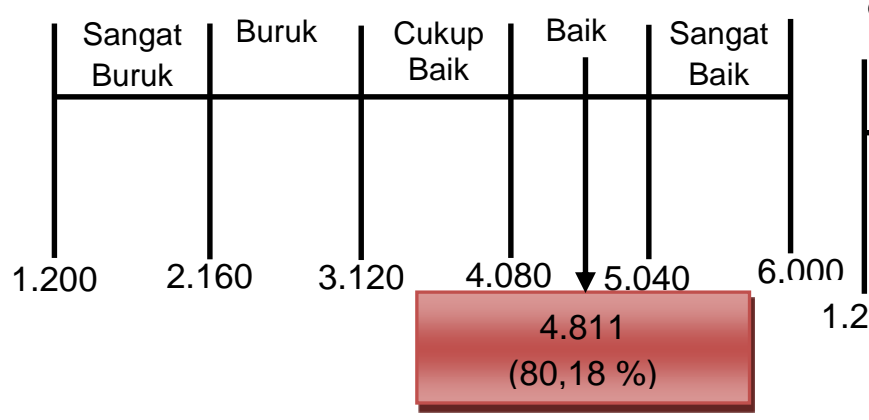

Gambar 4.1

Nilai The Attraction of Tour Pada Garis Kontinum

4.2 Hasil Tanggapan Responden Terhadap Kepuasan Wisatawan Berdasarkan Kepuasan Terhadap The Attraction of Tour

Tabel 4.2

REKAPITULASI TANGGAPAN RESPONDEN

TERHADAP KEPUASAN WISATAWAN BERDASARKAN KEPUASAN TERHADAP THE ATTRACTION OF TOUR

\begin{tabular}{|c|c|c|c|c|}
\hline No & Sub Variabel & $\begin{array}{l}\text { Total } \\
\text { Skor }\end{array}$ & $\begin{array}{c}\text { Skor } \\
\text { Rata- } \\
\text { rata }\end{array}$ & $\%$ \\
\hline 1 & $\begin{array}{c}\text { Kepuasan } \\
\text { Terhadap } \\
\text { Price }\end{array}$ & 1298 & 259.60 & 25.32 \\
\hline 2 & $\begin{array}{l}\text { Kepuasan } \\
\text { Terhadap } \\
\text { Expertise } \\
\end{array}$ & 1315 & 263.00 & 25.65 \\
\hline 3 & $\begin{array}{c}\text { Kepuasan } \\
\text { Terhadap } \\
\text { Convenience }\end{array}$ & 1271 & 254.2 & 24.79 \\
\hline 4 & $\begin{array}{c}\text { Kepuasan } \\
\text { Terhadap } \\
\text { Access }\end{array}$ & 1242 & 248.4 & 24.23 \\
\hline & Total & 5126 & 1025.2 & 100 \\
\hline
\end{tabular}

Sumber: Pengolahan Data 2015

Dari tabel 4.2 menunjukan bahwa nilai tertinggi dari kepuasan terhadap the attraction of tour adalah kepuasan terhadap expertise dengan bobot nilai sebesar $25,65 \%$ dan yang mendapatkan penilaian paling kecil adalah access dengan bobot nili sebesar 24,23\%. Hal tersebut mungkin dikarenakan wisatawan merasa lebih puas ketika mendapatkan pelayanan dari karyawan baik karyawan sebagai tour guide ataupun staf yang bertugas sebagai pemasar yang berhubungan langsung dengan wisatawan.

Total penilaian responden terhadap kepuasan wisatawan berdasarkan kepuasan terhadap the attraction of tour berjumlah 5.126, oleh karena itu kepuasan wisatawan berdasarkan kepuasan terhadap the attraction of tour dinyatakan dalam kondisi sangat baik dalam benak wsiatawan seperti yang ditunjukan dalam garis kontinum sebagai berikut:

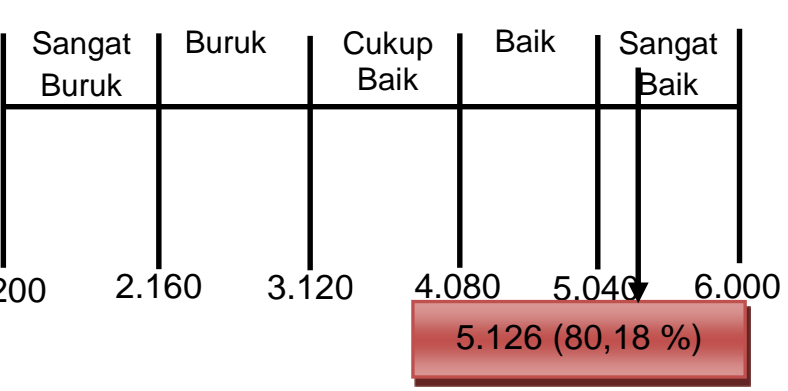

Gambar 4.2

Nilai Kepuasan Wisatawan Terhadap The Attraction of Tour Pada Garis Kontinum

\subsection{Pengaruh The Attraction Of Tour Terhadap} Kepuasan Wisatawan

4.3.1 Hasil Uji Hipotesis dan Uji Signifikansi Secara Simultan (Uji F)

Uji hipotesis secara simultan dilakukan dengan cara membandingkan nilai $\mathrm{F}$ hitung dengan F tabel, dengan kriteria pengambilan keputusan jika $\mathrm{F}_{\text {hitung }}<\mathrm{F}_{\text {tabel }}$ maka Ho diterima dan Ha ditolak dan jika $F_{\text {hitung }}>F_{\text {tabel }}$ maka Ho ditolak dan Ha diterima.

Tabel 4.3

\section{Hasil Output ANOVA}

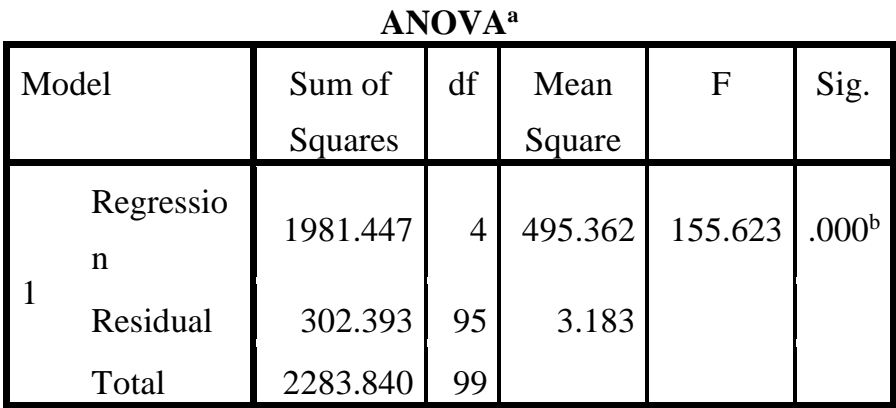

a. Dependent Variable: Y

b. Predictors: (Constant), X4, X1, X2, X3

Sumber: Pengolahan Data 2015

Berdasarkan Tabel 4.19 diperoleh nilai $F_{\text {hitung }}$ yaitu sebesar 155,623 , nilai ini lebih besar dari $F_{\text {tabel }}$ dengan derajat kebebasan 0,05 yaitu 2,46. hal tersebut dapat di gambarkan $F_{\text {hitung }}(155,623)>F_{\text {tabel }}$ $(2,46)$ dengan nilai signifikansi 0,000 . Nilai signifikansi lebih kecil dari taraf signifikansii 5\% menyatakan bahwa Ho ditolak dan Ha diterima. Secara statistik hipotesis dari penelitian ini dapat ditulis sebagai berikut : 
$\mathrm{Ha} \neq 0$, terdapat pengaruh the attraction of tour terhadap kepuasan wisatawan yang menggunakan jasa perjalanan wisata.

Secara keseluruhan penelitian mengenai the attraction of tour terhadap kepuasan wisatawan yang menggunakan jasa perjalanan wisata di TJP Seratour terdapat pengaruh yang signifikan antara the attraction of tour yang terdiri dari price, expertise, convenience dan access terhadap kepuasan wisatawan yang menggunakan jasa perjalanan wisata di TJP Seratour.

\subsubsection{Hasil Uji Hipotesis dan Uji Signifikansi Secara Parsial (Uji t)}

Uji hipotesis secara parsial dilakukan untuk mengetahui terdapat pengaruh yang nyata atau tidak antara sub variabel $\mathrm{X}$ terhadap variabel $\mathrm{Y}$. Uji $\mathrm{t}$ dilakukan dengan membandingkan $\mathrm{T}_{\text {hitung }}$ dengan $\mathrm{T}$ tabel.

\section{Tabel 4.4}

\section{Hasil Uji Parsial (Uji t)}

\section{Coefficients $^{\mathbf{a}}$}

\begin{tabular}{|l|r|r|r|c|c|}
\hline Model & \multicolumn{2}{|c|}{$\begin{array}{l}\text { Unstandardized } \\
\text { Coefficients }\end{array}$} & $\begin{array}{c}\text { Standard } \\
\text { ized } \\
\text { Coeffici } \\
\text { ents }\end{array}$ & $\mathrm{t}$ & Sig. \\
& \multicolumn{1}{|c|}{$\mathrm{B}$} & $\begin{array}{c}\text { Std. } \\
\text { Error }\end{array}$ & Beta & & \\
\cline { 2 - 4 } (Con & & & & & \\
stant & 2.238 & 2.187 & & 1.023 & .309 \\
) & & & & & \\
X1 & 1.095 & .176 & .254 & 6.227 & .000 \\
X2 & .933 & .131 & .314 & 7.128 & .000 \\
X3 & .832 & .171 & .254 & 4.868 & .000 \\
X4 & 1.199 & .155 & .403 & 7.751 & .000 \\
\hline
\end{tabular}

a. Dependent Variable: $Y$

Sumber: Pengolahan Data 2015

Nilai t tabel dapat dilihat pada degree of freedom yaitu 1,660. Berdasarkan Tabel 4.4 empat (4) sub variabel dari the attraction of tour memiliki pengaruh terhadap kepuasan wisatawan karena nilai thitungnya lebih besar dari t tabel. Nilai thitung dari price adalah $6,227>1,660$ nilai $\mathrm{t}$ tabel, hal ini menunjukan bahwa price memberikan pengaruh terhadap kepuasan wisatwan, sehingga Ho ditolak dan Ha diterima. Nilai t tabel expertise adalah 7,128 $>$ 1,660 nilai $t$ tabel, hal ini juga menunjukan bahwa sub variabel expertise memiliki pengaruh terhadap keputusan berkunjung, sehingga Ho ditolak dan Ha diterima. Nilai t hitung dari convenience adalah $4,868>1,660$ nilai $t$ tabel yang menunjukan bahwa convenience memiliki pengaruh terhadap kepuasan wisatwan sehingga Ho ditolak dan Ha diterima. Dan nilai thitung dari access adalah 7,751>1,660 t tabel yang juga menunjukan bahwa access memiliki pengaruh terhadap kepuasan wisatawan.

\subsubsection{Model Persamaan Regresi Berganda Pengaruh The Attraction of Tour Terhadap Kepuasan Wisatawan yang Menggunakan Jasa Perjalanan Wisata Di TJP Seratour}

Penelitian ini menggunakan analisis regresi berganda yang bertujuan untuk mengetahui pengaruh yang timbul dari variabel $\mathrm{X}$ yaitu the attraction of tour yang terdiri dari price (X1), expertise (X2), convenience (X3) dan access (X4) terhadap kepuasan wisatawan yang menggunakan jasa perjalanan wisata di TJP Seratour. Jika nilai koefisien atau arah dari variabel $\mathrm{X}$ menurun makan variabel $\mathrm{Y}$ akan ikut menurun, sebaliknya jika variabel $\mathrm{X}$ meningkat maka variabel $\mathrm{Y}$ akan ikut meningkat.

Penghitungan regresi dilakukan dengan menggunakan SPSS 20 for windows dan perolehan persamaanya sebagai berikut.

$\mathrm{Y}=\mathrm{a}+\mathrm{b}_{1} \mathrm{X}_{1}+\mathrm{b}_{2} \mathrm{X}_{2}+\mathrm{b}_{3} \mathrm{X} 3+\mathrm{b}_{4} \mathrm{X}_{4}$ $\mathrm{Y}=2,238+1,095 \mathrm{X}_{1}+0,933 \mathrm{X}_{2}+0,832 \mathrm{X}_{3}+1,199 \mathrm{X}_{4}$

Keterangan:

$\mathrm{Y} \quad=$ Kepuasan Wisatawan

a $\quad=$ Konstanta

$\mathrm{b}_{1}, \mathrm{~b}_{2}, \quad=$ angka arah atau koefisien regresi

$\mathrm{X}_{1} \quad=$ price

$\mathrm{X}_{2} \quad=$ expertise

$\mathrm{X}_{3}=$ convenience

$\mathrm{X}_{4} \quad=$ access

Secara lengkap pengaruh masing-masing dimensi dari the attraction of tour dalam meningkatkan kepuasan wisatawan, ditampilkan dalam Gambar 4.9 berikut.

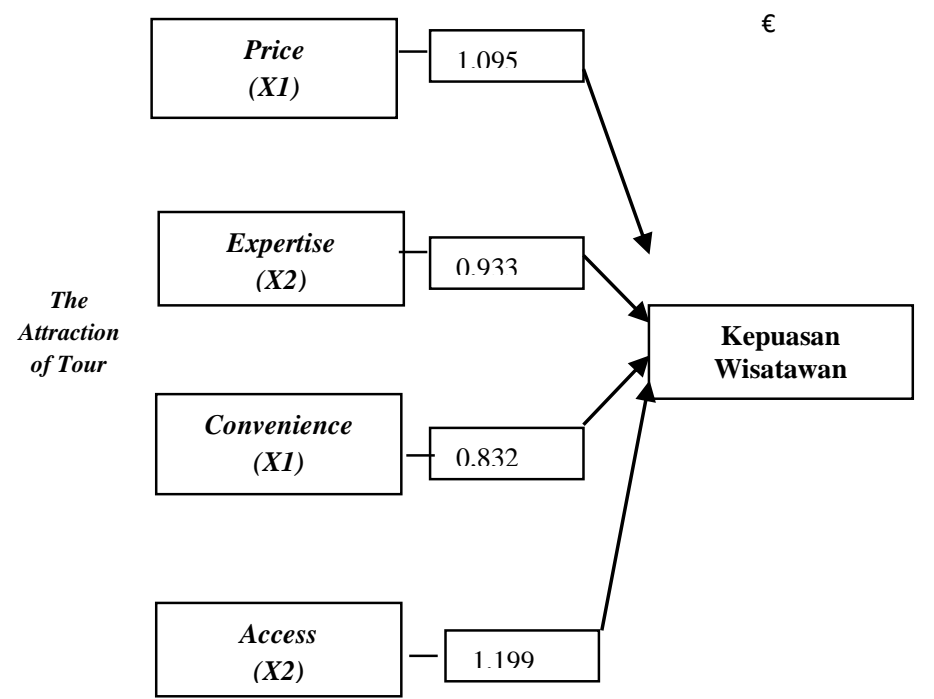

Gambar 4.3

Diagram Struktur Hipotesis

\subsection{Implikasi Hasil Penelitian}

4.4.1 Temuan Hasil penelitian yang bersifat teoritik 
1. Hasil temuan penelitian, peneliti memperkuat konsep the attracton of tour yang dijelaskan oleh Warwick Frost (2004) bahwa the attraction of tour didalamnya terdapat sub variabel price, expertise, convenience dan access.

2. Berdasarkan temuan peneliti memperkuat konsep kepuasan wisatawan yang diadaptasi dari kepuasan wisatwan yang dijelaskan oleh Kotler dan Keller (2012) yang dibagi kedalam 2 dimensi yaitu harapan konsumen dan kenyataan yang dirangkum dalam pernyataan puas atau tidak guna memudahkan responden dalam menjawab pertanyaan dalam kuisioner dan memudahkan penulis dalam proses penghitungan.

3. Dalam penelitian ini juga peneliti memperkuat konsep pengaruh tour package terhadap kepuasan wisatawan yang di adopsi dari David Bowie dan Jui Chi Chang (2005)

\subsubsection{Temuan Hasil Penelitian yang Bersifat Empirik}

1. Peneliti menemukan bahwa the attraction of tour memiliki pengaruh yang signifikan dalam mempengaruhi kepuasan wisatawan yang menggunakan jasa perjalanan wisata di TJP Seratour dikarenakan wisatawan merasakan pengalaman berwisata dengan menggunakan jasa perjalanan wisata yang sesuai dengan harga yang dapat wisatawan bayar, merasakan kenyamanan dalam berwisata, merasakan pelayanan yang baik dan mendapatkan pengalaman dalam memilih produk yang baik dan cocok untuk memenuhi keinginan berwisatanya.

2. Berdasarkan penelitian yang dilakukan meneliti menemukan bahwa wisatawan yang merasa puas setelah menggunakan jasa perjalanan wisata di TJP Seratour dikarenakan wisatawan merasakan kecocokan harga, keahlian karyawan dalam melakukan pelayanan, kenyamanan dan kepuasan dalam mendapatkan akses menuju daerah tujuan wisata yang diinginkan.

3. Pengaruh yang paling tinggi terhadap keputusan berkunjung wisatawan adalah aexpertise dan convenience, hal ini disebabkan wisatawan yang menggunakan jasa perjalanan wisata akan sangat menilai keahlian karyawan dalam melayani keinginan dan kebutuhan wisatawan, selain itu juga wisatawan menilai dari sisi kenyamanan pada saat mereka melakukan kegiatan berwisata menggunakan jasa perjalanan wisata.
Dimensi lainnya juga memberikan kontribusi yang baik dalam mempengaruhi kepuasan wisatawan, akan tetapi mungkin dimensi tersebut kurang dimaksimalkan oleh perusahaan dalam pengaplikasiannya terhadap wisatawan yang menggunakan jasa perjalanan wisata.

\section{Kesimpulan dan Rekomendasi}

\subsection{Kesimpulan}

1. The attraction of tour merupakan salah satu strategi untuk menarik minat wisatawan menggunakan jasa perjalanan wisata dan memberikan kepuasan tersendiri bagi wisatawan yang menggunakan jasa perjalanan wisata melalui pelayanan yang diberikan oleh karyawan dan kapabilitas suatu agen perjalanan wisata dalam memenuhi kebutuhan dan keinginan wisatawan dalam melakukan kegiatan berwisatanya. Didalam strategi the attraction of tour terdapat beberapa sub variabel yang menjadi faktor pendorong wisatawan untuk menggunakan jasa perjalanan wisata dan merasakan kepuasan setelah menggunakan jasa peejalanan wisata yang diinginkan, salah satunya ada price, expertise, convenience dan acces yang membuat wisatawan tertarik untuk menggunakan jasa perjalanan wisata dikarenakan kemenarikan harga, kenyamanan, kesiapan karyawan dalam melayani, dan berbagai macam opsi pilihan daerah tujuan wisata yang dapat dituju oleh wisatawan, hal tersebut juga dapat menimbulkan kepuasan wisatawan setelah menggunakan jasa perjalanan wisata dengan melihat kesesuaian harga yang dibayar dengan fasilitas yang diberikan, pelayanan yang diberikan dan kenyamanan yang dirasakan oleh wisatawan saat melaksanakan kegiatan berwisatanya.

2. Kepuasan wisatawan di TJP Seratour mendapatkan penilaian yang baik sesuai dengan garis kontinum. Kepuasan wisatawan mengadopsi teori dari kepuasan konsumen menurut Kotler dan Keller (2012).

3. Hasil penelitian yang telah dilakukan menunjukan adanya pengaruh yang signifikan antara the attraction of tour yang terdiri empat dimensi yaitu price, expertise, convenience dan access terhadap kepuasan wisatawan yang menggunakan jasa perjalanan wisata di TJP Seratour. Dengan demikian dapat disimpulkan bahwa strategi the attraction 
of tour yang diterapkan di TJP Seratour memiliki nilai positif dan sudah tercipta dengan baik sehingga dapat mempengaruhi kepuasan wisatawan setelah menggunakan jasa perjalanan wisata di TJP Seratour.

\subsection{Rekomendasi}

1. Secara umum wisatawan yang menggunakan jasa perjalanan wisata di TJP Seratour merasakan kepuasan setelah menggunakan jasa perjalanan wisata di TJP Seratour, akan tetapi tidak ada salahnya juga untuk perusahaan meningkatkan kualitas dari beberapa aspek yang mampu mempengaruhi kepuasan wisatawan yang menggunakan jasa perjalanan wisata di TJP Seratour, salah satunya adalah merekrut karyawan yang lebih berpengalaman dalam bidang nya, baik karyawan yang bertugas di kantor maupun di lapangan, meningkatkan jaringan kerjasama antar penyedia jasa pariwisata lainnya seperti daerah tujuan wisata, penyedia jasa transportasi, hotel dan yang lainnya guna memberikan kenyamanan dan pelayanan yang baik kepada wisatawan sehingga wisatawan akan mersa lebih puas ketika menggunakan jasa perjalanan wisata.

2. Kepuasan wisatawan yang telah diciptakan oleh TJP Seratour sudah dalam kategori baik, dalam penelitian ini pun dapat dilihat bahwa penilaian wisatawan mengenai kepuasan wisatawan di TJP Seratour telah mencapain kategori baik seerti yang ditunjukan dalam garis kontinum dalam penelitian ini, oleh karena itu pihak perusahaan harus mempertahankan hal tersebut, dan alangkah lebih baiknya jika perusahaan meningkatkannya dan memberikan hal - hal baru untuk mendorong kepuasan wisatawan.

3. Penelitian ini menunjukan adanya pengaruh yang cukup tinggi antara the attraction of tour terhadap kepuasan wisatawan, sehingga akan lebih baik apabila pihak perusahaan dapat mempertahankan bahkan mengembangkan faktor - faktor lainnya yang dapat menciptakan kepuasan wisatawan untuk mendorong penciptaan kepuasan wisatawan lebih baik lagi dan menambah kredibilitas dan memajukan perusahaan karena memiliki pelayanan dan produk terbaiknya dibenak wisatawan.
Al-Ababneh, Mukhles. 2013. Service Quality and its Impact on Tourist Satisfaction. Ma'an. ijcrb.webs.com.

Berenson, Mark L et al. 2012. Basic Business Statistics Concept and Aplication $12^{\text {th }}$ edition : Prentince Hall.

Bowie, David and Chang, Jui Chi 2005. Tourist satisfaction: A view from a mixed international guided package tour.

Cengiz, emrah. 2010. Measuring Customer Satisfaction: Must Or Not?. (Measuring Customer Satisfaction: Must Or Not?, hal:78).

Chan, Andrew. Hsu, Cathy H.C. Baum, Tom. The Impact of Tour Service Performance on Tourist Satisfaction and Behavioral Intentions: A Study of Chinese Tourists in Hong Kong. London. Routledge.

Clemes, Michael D. Gan, Christoper. Ren, Min. 2011. Synthesizing the Effects of Service Quality, Value, and Customer Satisfaction on Behavioral Intentions in the Motel Industry: An Empirical Analysis. Sage Publication Ltd (Synthesizing the Effects of Service Quality, Value, and Customer Satisfaction on Behavioral Intentions in the Motel Industry: An Empirical Analysis. 532).

Corte, Valentina Della. Sciarelli, Mauro. Cascella, Clelia. Gaudio, Giovanna Del. 2015. SelfService Customer satisfaction in tourist destination: The case of tourism offer in the city of Naples. Science Publishing Group.

Esu, Bassey Benjamin. 2009. Tourists' Satisfaction with Cultural Tourism Festival: a Case Study of Calabar Carnival Festival, Nigeria. Calabar. www.ccsenet.org/journal.html.

Frost, Warwick. 2004. Travel \& Tour Management. Australia. Pearson Hospitality Press.

Goeldner, C. R. Ritchie, J. R. Brent. (2009). Tourism Principles Practices Philophies. $7^{\text {th }}$ edition. New Jersey: John Wiley \& Sons Inc.

Hasan, Ali. 2008. Marketing. Yogyakarta: Media Presindo.

Hudson, Simon. 2008. Tourism and Hospitality Marketing : A Global Perspective. Los Angles. Sage Publication Ltd. 
Nugraha Adi Saputra, Oce Ridwanudin 